\title{
Myiarchus flycatchers are the primary seed dispersers of Bursera longipes in a Mexican dry forest
}

R. Carlos Almazán-Núñez, Luis E. Eguiarte, María del Coro Arizmendi, Pablo Corcuera

We evaluated the seed dispersal of Bursera longipes by birds along a successional gradient of tropical dry forest (TDF) in southwestern Mexico. $B$. longipes is an endemic tree to the TDF in the Balsas basin. The relative abundance of frugivorous birds, their frequency of visits to $B$. longipes and the number of removed fruits were recorded at three study sites with different stages of forest succession (early, intermediate and mature) characterized by distinct floristic and structural elements. Flycatchers of the Myiarchus and Tyrannus genera removed the majority of fruits at each site. Overall, visits to $B$. longipes were less frequent at the early successional site. Birds that function as legitimate dispersers by consuming whole seeds and regurgitating or defecating intact seeds in the process also remove the pseudoaril from seeds, thereby facilitating the germination process. The highest germination percentages were recorded for seeds that passed through the digestive system of two migratory flycatchers: $M$. cinerascens and $M$. nutingii. Perch plants, mainly composed of legumes (e.g., Eysenhardtia polystachya, Acacia cochliacantha, Calliandra eryophylla, Mimosa polyantha), serve also as nurse plants since the number of young individuals recruited from $B$. longipes was higher under these than expected by chance. This study shows that Myiarchus flycatchers are the most efficient seed dispersers of $B$. longipes across all successional stages. This suggests a close mutualistic relationship derived from adaptive processes and local specializations throughout the distribution of both taxa, as supported by the geographic mosaic theory of coevolution. 
1 Myiarchus flycatchers are the primary seed dispersers of Bursera longipes in a Mexican dry

2

3

4

5

$6{ }^{1}$ Laboratorio Integral de Fauna Silvestre, Unidad Académica de Ciencias Químico Biológicas,

7 Universidad Autónoma de Guerrero, Chilpancingo, Guerrero, México

8 2Laboratorio de Evolución Molecular y Experimental, Departamento de Ecología Evolutiva,

9 Instituto de Ecología, Universidad Nacional Autónoma de México, México, D.F. forest

${ }^{3}$ Laboratorio de Ecología, Unidad de Biotecnología y Prototipos, Universidad Nacional

Autónoma de México, México, D.F.

${ }^{4}$ Departamento de Biología, Universidad Autónoma Metropolitana-Iztapalapa, México, D.F.
Av. San Rafael Atlixco 186, Col. Vicentina Iztapalapa, C.P. 09340, Mexico, D.F. Mexico

Email address: pcmr@xanum.uam.mx 
24 Abstract. We evaluated the seed dispersal of Bursera longipes by birds along a successional

25

26 gradient of tropical dry forest (TDF) in southwestern Mexico. Bursera longipes is endemic to TDF in the Balsas basin. Frequency of frugivorous bird visits to B. longipes and number of fruits removed by birds were recorded at three study sites with different stages of forest succession (early, intermediate and mature) characterized by distinct floristic and structural elements. Flycatchers of Myiarchus and Tyrannus genera removed the majority of fruits at each stage. Overall, visits to B. longipes were less frequent in the early successional stage. Birds that function as legitimate dispersers by consuming whole seeds and then regurgitating or defecating intact seeds also remove the pseudoaril from seeds during this process, which facilitates germination. The highest germination percentages were recorded for seeds that passed through the digestive system of two migratory flycatchers: $M$. cinerascens and $M$. nutingii. Perch plants, mainly composed of Fabaceae species (e.g., Eysenhardtia polystachya, Acacia cochliacantha, Calliandra eryophylla, Mimosa polyantha), were found to also serve as nurse plants, since the number of young individuals recruited from B. longipes was higher under these plants than what would be expected by chance. This study shows that Myiarchus flycatchers are the most efficient seed dispersers of $B$. longipes across all successional stages, which suggests a close mutualistic relationship resulting from processes of adaptation and local specialization throughout the distribution of both taxa. 


\section{Introduction}

Biotic seed dispersal plays a central role in the spatial dynamics of plant populations (Spiegel \& Nathan, 2007; Schupp, Jordano \& Gómez, 2010; Jordano et al., 2010, Forget et al., 2011). Dispersion may encourage establishment of plants, since intraspecific competition is generally lower in sites distant from the parent plant (Godínez-Alvarez, Valiente-Banuet \& Rojas-Martínez, 2002; Schupp, Milleron \& Russo, 2002). Moreover, the incidence of pathogens and predators is usually lower at new sites, where the seeds are dispersed by animals (Jordano et al., 2010; Obeso, Martínez \& García, 2011).

In arid and semi-arid environments, biotic dispersal, germination and seedling establishment are critical phases of the plant life cycle (Valiente-Banuet et al., 1991; GodínezAlvarez \& Valiente-Banuet, 1998; Orozco-Almanza et al., 2003; Padilla \& Pugnaire, 2006). During the dry season, for example, seedlings face adverse conditions, such as dry soil, direct sunlight and extreme temperatures (Godínez-Alvarez \& Valiente-Banuet, 1998). However, dispersers may deposit seeds in preferable microhabitats (i.e., under nurse plants) that promote germination and seedling survival (Pérez-Villafaña \& Valiente-Banuet, 2009). Yet in arid environments, few microhabitats with suitable conditions exist, and certain microhabitats may in fact adversely affect seedling establishment (Calviño-Cancela \& Martín-Herrero, 2009). Thus, the role of dispersers in depositing seeds in sites with appropriate conditions for germination in these environments is particularly important because there are few adequate microhabitats in which seeds can be established (Vasconcellos-Neto, Barbosa \& Rodrigues, 2009).

The relative contribution of seed dispersal by birds towards plant fitness has been assessed by “seed dispersal effectiveness," or SDE (Schupp, 1993; Schupp, Jordano \& Gómez, 2010). Seed dispersal effectiveness has a quantitative (i.e., number of seeds dispersed) and a 
70 qualitative (i.e., probability that seeds reach adult stage) component that is mainly dependent on

71 feeding behavior and movement patterns of dispersers (Calviño-Cancela, 2002; Calviño-Cancela

72 \& Martín-Herrero, 2009), in addition to other functional traits, such as body size (Escribano-

73 Avila et al., 2014). For example, retention time of seeds may vary between different bird species

74 depending on gut length, and as a consequence, dispersers defecate seeds with different degrees

75 of scarification (i.e., the process by which gastric juices weaken the seed coat, encouraging

76 germination; Robertson et al., 2006). Large differences in SDE among dispersers generally

77 signifies that dispersion processes are complementary and non-redundant (Escribano-Avila et al.,

78 2014). However, differences in effectiveness depend not only on morphological traits but also on

79 deposition of seeds in suitable microhabitats (e.g., type of microhabitat; Calviño-Cancela \&

80 Martín-Herrero, 2009).

81 Different aspects of seed dispersal are being modified by the transformation of natural

82 communities worldwide by human activities (Wright, 2007). For instance, inadequate

83 agricultural practices have reduced once undisturbed portions of tropical dry forest (TDF) in

84 Mesoamerica to fragments of various successional stages (Quesada et al., 2009). Since the soil

85 seed bank may be considerably reduced in disturbed fragments (Uhl, 1987; Martins \& Engel,

86 2007), seed dispersal can play an important role in the recruitment of plants and hence contribute

87 towards the composition and density of woody plants and the eventual restoration of these forests

88 (Hammond, 1995; Peña-Claros \& De Boo, 2002).

89 The vegetation of the Balsas basin in southwestern Mexico consists mainly of TDF

90 (Rzedowski, 1978). In these forests, the dominant arboreal elements generally belong to the

91 genus Bursera, or Burseraceae (Rzedowski, Medina \& Calderón de Rzedowski, 2005; Almazán-

92 Núnez et al., 2012), whose fruits are a food source for resident and migratory frugivorous and 
93 insectivorous birds during the dry season (Ortiz-Pulido \& Rico-Gray, 2006; Ramos-Ordoñez \&

94 Arizmendi, 2011). Furthermore, the distribution of these birds throughout different successional

95 stages of TDF is related to the presence of these trees (Almazán-Núñez et al., 2015).

$96 \quad$ Although the role of birds as consumers and dispersers of Bursera spp., including

97 flycatchers and vireos, has been previously described (Greenberg, Foster \& Márquez-

98 Valdelamar, 1995; Hammond, 1995; Ortiz-Pulido \& Rico-Gray, 2006; Ramos-Ordoñez \&

99 Arizmendi, 2011), there are few detailed reports on this subject. Several examples include the

100 studies of Ramos-Ordoñez \& Arizmendi (2011), who performed an analysis of seed dispersal by

101 B. morelensis, and Ortiz-Pulido \& Rico-Gray (2006), who examined the same process in $B$.

102 fagaroides. No additional studies have been performed in TDF to evaluate or compare biotic

103 seed dispersal between sites with different degrees of disturbance (Hammond, 1995; Quesada et

104 al., 2009). Furthermore, the majority of studies on frugivory and seed dispersal have been limited

105 to single locations (Ortiz-Pulido \& Rico-Gray, 2006; Ramos-Ordoñez \& Arizmendi, 2011). This

106 represents a significant potential bias, as patterns that remain elusive at local scales may emerge

107 in regional studies covering areas with varying levels of disturbance or recovery (Carlo, Aukema

$108 \&$ Morales, 2007). Frugivory and seed dispersal may also differ across a geographic mosaic, as

109 interacting species may not necessarily have the same distribution (Thompson, 2005). There is a

110 need for studies to elucidate patterns of biotic seed dispersal and seedling establishment in TDF,

111 considering different levels of perturbation or seral stages, in order to create a scientific basis for

112 the application of management and conservation strategies in these forests.

113 In this study, we describe the primary seed dispersal of B. longipes by frugivorous birds

114 in a TDF of the Balsas basin of Guerrero. B. longipes belongs to the Simaruba sub-group of the

115 diverse Bursera genus and forms part of a larger clade that emerged during the Miocene slightly 
116 over 8.5 million years ago (De-Nova et al., 2012). In addition, it is a dominant tree species

117 (Almazán-Núñez et al., 2012) in this biotic region, which is considered to be the center of

118 diversification for this genus in Mesoamerica (Rzedowski, Medina \& Calderón de Rzedowski,

119 2005). While $B$. longipes abundance increases in well-preserved sites, it is also found in

120 disturbed areas (Rzedowski, Medina \& Calderón de Rzedowski, 2005). The adaptability of $B$.

121 longipes to disturbed environments may promote the regeneration of TDF of the Balsas basin

122 and help to reverse fragmentation (Ramos-Ordoñez, Arizmendi \& Márquez-Guzmán, 2012).

123 However, its seeds have a hard coat and must be consumed by a frugivore in order to be

124 scarified, and afterwards dispersed (Ramos-Ordoñez \& Arizmendi, 2011).

The study was centered on the following questions: (1) Which bird species remove $B$.

126 longipes seeds along a successional gradient of TDF? (2) Do seeds that pass through the

127 digestive tract of birds have higher germination rates than those that fall from trees? (3) Do

128 differences exist in the quality of seeds dispersed by birds? (4) Does B. longipes require nurse

129 plants in different successional stages? (5) Do seed-dispersing birds preferentially use nurse

130 plants for perching across all successional stages?

131

132 Materials \& Methods

133 Study sites

134 We conducted the study at three different successional stages of TDF that have been

135 mostly unmanaged for varying periods of time since their last major disturbance (i.e., clear-

136 cutting or burning). The three stages are described as follows: (1) The early successional stage

137 (last disturbed ca. $20 \mathrm{y}$ ago) consisted of vegetation regrowth in a plot once used for cattle

138 ranching and, to a lesser extent, seasonal agriculture. (2) The intermediate successional stage 
139 (last disturbed $c a .35 \mathrm{y}$ ago) corresponded with a transitional phase between a mature forest and

140 fragmented areas with a matrix of pasture and seasonal corn and bean fields, yet was once

141 dedicated to seasonal corn production and cattle ranching. Structural and floristic elements had

142 developed that mirrored the original dry forest vegetation, to a large extent. (3) The mature

143 successional stage was characterized by a closed canopy and presence of tree cover typical of

144 mature dry forest (i.e., dominance of the Bursera spp.). This stage has not experienced a large

145 scale disturbance for more than 50 years.

146 The successional stages were found in patches with areas of 97 ha (early stage), 45.3 ha

147 (intermediate stage) and 24 ha (mature stage). The mean distance between successional stages

148 was $c a .1 \mathrm{~km}$ (Fig. 1).

149

150

Bursera longipes

151

The genus Bursera is a distinctive component of TDF in Mesoamerica and is composed

152

of $c a .107$ species (De-Nova et al., 2012). Its distribution spans from northern Mexico to the

153

northern region of South America (Becerra et al., 2012). The diversification of this genus is

154 related to the southward expansion of TDF in response to the elevation of the Sierra Madre del

155 Sur and the Mexican Volcanic Belt (De-Nova et al., 2012). Bursera evolutionary history

156 indicates that a large portion of the biological richness of Mesoamerican TDF was derived from

157 accelerated rates of speciation in habitats, from the early Miocene to the Pliocene, during

158 pronounced arid periods (Becerra, 2005; Dick \& Wright, 2005). This scenario matches other

159 hypotheses that these lineages were mostly restricted to dry environments of Mexico and evolved

160 during long periods of isolation (Valiente-Banuet et al., 2004). 
162 Puebla, Guerrero and Oaxaca in the Balsas basin (Fig. 1; Rzedowski, Medina \& Calderón de

163 Rzedowski, 2005). It is a deciduous species with trivalvate fruits that turn red at maturity; seeds

164 have a slightly orange pseudoaril (Guízar \& Sanchez, 1991). Fruits are $1.3 \pm 0.02 \mathrm{~cm}(\mathrm{mean} \pm$

$165 \mathrm{SE})$ in length and $0.87 \pm 0.04 \mathrm{~cm}$ in width, with a fresh weight of $0.62 \pm 0.01 \mathrm{~g}(N=100$ fruits $)$.

166 Flowering season begins with the onset of the rainy season (May or June), and fruiting occurs in 167 early June or from May-July. Most fruits ripen between November and May.

\section{Seed dispersal effectiveness}

In this study we used the quantitative and qualitative components proposed by Schupp

171 (1993) and Schupp, Jordano \& Gómez (2010) to estimate the effectiveness of B. longipes seed

172 dispersal in each successional stage. The quantitative component included the frequency of visits

173 to $B$. longipes tree and the average number of fruits removed per visit by frugivorous birds. The

174 qualitative component was based on the percentage of germination after seeds passed through the

175 digestive system of birds, the probability of seed deposition under a nurse plant (adult plants that

176 positively influence the recruitment of young seedlings) and the possible contribution of bird

177 species to the establishment of $B$. longipes after seed deposition under nurse plants (Schupp,

178 Jordano \& Gómez, 2010). Seed dispersal effectiveness of each frugivore is calculated as the

179 product of the subcomponents of quantity and quality, according to the following expression

180 (Schupp, 1993; Schupp, Jordano \& Gómez, 2010): Effectiveness = frequency of visits x average

181 number of removed fruits per visit $\mathrm{x}$ proportion of seed germination $\mathrm{x}$ seed deposition probability

182 in potential suitable microhabitats $\mathrm{x}$ contribution of birds to site of establishment. 


\section{Quantitative component}

185

186

187

188

190

191

192

193

194

195

196

197

198

199

200

201

202

203

204

205

206

207

\section{Frequency of visits and average amount of removed fruit}

Frequency of visits was determined by focal observations using binoculars $(8 \times 40 \mathrm{~mm})$.

Observations were focused on seven B. longipes individuals with ripe fruits at each successional stage and performed during January-May 2011 and March-May 2012 in the morning (0700$1130 \mathrm{~h})$ and afternoon (1600-1830 h), when bird activity is higher. Each of the seven trees was sampled in each successional stage during both years. A total of 70 hours of observation was recorded for each successional stage (10 hours / tree), for a total of 210 hours in all three stages. Each tree was observed at a distance of $\sim 20$ to $30 \mathrm{~m}$ for an observational period of 30 min, during which the frugivore species and number of visits were recorded, in addition to number of individuals, total time of visit (from arrival to departure) and number of fruits consumed per visit. The frequency of visits was analyzed in a $\chi^{2}$ contingency table to determine differences among successional stages. In this case, the null hypothesis would indicate the existence of an equal number of visits between successional stages. The number of removed fruits was compared among stages with an unbalanced one-way ANOVA. For this analysis, data were transformed $(\log x+1)$ to meet assumptions of normality and homogeneity of variance.

\section{Qualitative component}

\section{Seed germination}

Seeds obtained from the faeces of birds captured by nine $12 \mathrm{~m}$ mist nets in each successional stage were used to determine the effect of passage of seeds through bird digestive system on the proportion of germination. Mist nets were placed during the months with greatest availability of mature B. longipes fruits (May and December 2010, January-May and December 
2082011 and March-May 2012). During each period, sampling was performed for 15 days. Mist

209 nets remained open from 07:00 to 18:00 hours, resulting in a total of 1485 net-hours per stage

210 and 4455 net-hours for all successional stages.

211 Captured birds were placed in individual cages $(40$ x $40 \mathrm{~cm})$ lined with mosquito netting

212 and fed ad libitum with ripe B. longipes fruits for a day after capture. Retention time of seeds

213 was estimated from the moment of fruit consumption until defecation or regurgitation of seeds.

214 Birds placed in cages were monitored every $10 \mathrm{~min}$, with the least possible disturbance, in order

215 to confirm their consumption of seeds with pseudoarils. Defecation times were recorded at 10

216 min inspection intervals. Retention time of seeds is therefore an approximation, according to

217 these intervals.

218 The premise in this portion of the study is that longer retention times would likely result

219 in seeds being spread farther from the mother plant (Westcott \& Graham, 2000). After

220 evacuation, feces were collected, and birds were released. Since the techniques used to collect

221 regurgitated seeds and feces were non-invasive, special authorizations were not required.

222

Seed viability was tested via flotation tests, in which floating seeds were considered

223

224

225

226

227

228

229

230

nonviable due to lack of embryonic development (Thompson, Grime \& Mason, 1997). Viable

seeds were washed with $10 \%$ sodium hypochlorite, planted in cotton on petri dishes at ambient temperature and moistened daily with distilled water. This procedure was performed with seeds obtained from different sources and with different treatments as follows: a) control group 1:

seeds with pseudoaril obtained directly from the trees, b) control group 2: seeds without pseudoaril obtained from trees and c) seeds that passed through the digestive system of birds. For the final treatment, the germination experiment was only performed with bird species from which the largest number of seeds was obtained: Myiarchus nuttingi $(N=67)$, Myiodynastes 
231 luteiventris $(N=58)$, Myiarchus cinerascens $(N=33)$, Melanerpes chrysogenys $(N=29)$ and

232 Myiarchus tyrannulus $(N=27)$. A total of 50 seeds per successional stage were used for each of

233 the controls (fruits obtained from trees).

234 In the first phase of the germination experiment, we mixed the seeds of the control groups

235 from all three stages and assigned a random number to each control treatment. Each control

236 group had a total of five replicates with 30 seeds each. The objective of this portion of the

237 experiment was to evaluate the effect of deinhibition and scarification (Robertson et al., 2006).

238 Germination experiments were performed directly in the field, where boxes with $B$.

239 longipes seeds were placed under the canopy of nurse plants Mimosa polyantha and Senna

240 wislizenni, which are commonly used by disperser birds for perching. The boxes were protected

241 with mesh mosquito netting and boric acid was poured around the perimeter to avoid predation

242 by ants. Over the course of 20 days, boxes were checked daily to count the number of

243 germinated seeds. The emergence of a radicle indicated germination.

244 The estimated retention time that seeds remained in the digestive system of birds was

245 compared between treatments with a one-way ANOVA, following a prior analysis of normality

246 and homoscedasticity. The null hypothesis was that time of retention would be the same for all

247 treatments. Multiple comparisons were analyzed with a Tukey HSD. The percentage of

248 germinated seeds was analyzed using a generalized linear model (GLM) with a binomial

249 distribution error and a logit link function (Crawley, 2012) to determine significant differences

250 between treatments. Post hoc pairwise t-test comparisons were carried out for each germination

251 treatment. To evaluate the effect of passage time through the bird gut on seeds on germination

252 percentage, we performed a linear regression (Traveset, 1998). In addition, we also analyzed the

253 relationship between the total body length of captured birds and the percentage of germinated 
254 seeds. The null hypothesis of this test was that a positive relationship would exist between these

255 variables. We measured body length using a digital calibrator, according to the specifications

256 given by Ralph et al., (1996). Analyses were performed with SPSS 17.0 software (SPSS, 2008).

257

258

Potential suitable sites for recruitment

259

Frugivorous birds deposit faeces under their perch trees (Vasconcellos-Neto, Barbosa \&

260

261

262

263

264

265

266

267

268

269

270

271

272

273

274

275

276

Rodrigues, 2009), but only the canopy of certain shrubs and trees provides suitable conditions for recruitment of seeds in arid environments (Godínez-Alvarez, Valiente-Banuet \& Rojas-Martínez, 2002). The deposition of seeds under the cover of trees or shrubs (potential nurse plants) was estimated by focal observations to record the number of visits to these perching sites by birds after fruit consumption. To facilitate the monitoring of birds after they finished eating and departed to fly in another direction or roost on another plant, one person was dedicated to postconsumer observations.

The number of visits of frugivorous birds to each of the following categories of perch plants was recorded: 1) conspecific, indicating that the individual remained in the same plant species (i.e., B. longipes) where they ate fruit; 2) Fabaceae species, including trees and shrubs of the Caesalpinoideae, Faboideae and Mimosoideae subfamilies, which have been identified as potential nurse plants in semi-arid environments (Godínez-Álvarez \& Valiente-Banuet, 1998) or 3) other tree or shrub plants, including species of Opuntia or columnar Cactaceae. Focal observations ended when eye contact with observed birds was lost. A contingency table of $\chi^{2}$ was used to compare the number of bird visits to each category of perch plant. The null hypothesis would be indicated by an equal number of bird visits among all perch categories across the three successional stages. Standardized residuals were used to evaluate the preferential use of certain 
277 perching sites by birds (Valiente-Banuet et al., 1991; Godínez-Alvarez, Valiente-Banuet \&

278 Rojas-Martínez, 2002). These residuals are distributed around a mean of 0 with a standard

279 deviation of 1 , and therefore, any resulting value $\geq 2$ (approximately $5 \%$ of the normal

280 distribution) was considered to be a significant deviation.

281

The probability that seeds were deposited in potentially suitable sites (under Fabaceae)

282

283

284

285

286

287

288

289

290

291

292

293

294

295

296

297

298

299

was determined by the proportion of frugivore visits to these perch plants in relationship to the total number of recorded visits. Fabaceae plants have been shown to provide appropiate conditions for the recruitment of seedlings (Godínez-Alvarez \& Valiente-Banuet, 1998).

\section{Contribution of birds to seedling establishment in different successional stages}

Two plots with a radius of $30 \mathrm{~m}\left(2828 \mathrm{~m}^{2}\right.$ per plot $)$ were randomly chosen in each successional stage. In each plot seedlings and young individuals of $B$. longipes (height $<50 \mathrm{~cm}$ ) were counted under trees or shrubs used by birds to roost after ingesting B. longipes fruits. Recruited individuals were classified by the previously mentioned categories of nurse plants; these categories have been successfully used in others studies in semiarid forests (ValienteBanuet et al., 1991; Godínez-Alvarez, Valiente-Banuet \& Rojas-Martínez, 2002). The number of young $B$. longipes plants observed under nurse plants was compared to the number of individuals expected to be recruited at random, derived from examining a proportional and comparable area and counting $B$. longipes underneath all plants with a DBH $\geq 10 \mathrm{~cm}$ (Valiente-Banuet et al., 1991). The null hypothesis would indicate a proportional number of seedlings between the comparative plots, given the coverage of woody plants. Standardized residuals were calculated to analyze the significance. Plant cover was determined in a previous study corresponding to the study sites (Almazán-Nuñez et al., 2012). 
towards the establishment of $B$. longipes. This value was estimated from individual observations

302

303

304

305

306

307

308

309

310

311

312

313

314

315

316

317

318

319

320

321

of bird species after feeding on B. longipes drupes, their flight destination and number of visits to other plants. The maximum value was assigned to birds with the highest number of flights to

nurse plants under which the largest number of seedlings or young $B$. longipes individuals had been observed with respect what would be expected by chance, according to the standardized residuals for each plot.

\section{Results}

\section{Quantitative component}

\section{Frequency of visits and number of removed fruits}

A total of 20 bird species were recorded eating B. longipes fruits (Table 1). Frequency of visits to remove fruit varied between stages $\left(X^{2}=54.78, d f=38, p<0.05\right)$. Myiarchus tyrannulus and Tyrannus verticalis were the most frequent visitors to the early successional stage (Table 1$), T$. vociferans and $T$. verticalis to the intermediate stage and $M$. cinerascens to the mature stage. Spinus psaltria removed the greatest number of fruit at the early $(5.00 \pm 1.58)$ and intermediate (4.40 \pm 0.51 ; Table 1$)$ stages and Eupsittula canicularis at the mature stage $(11.00 \pm$ 4.00).

Overall, $17.9 \%$ of the fruits consumed in the three stages were removed at the early stage, $42.2 \%$ at the intermediate stage and $39.9 \%$ at the mature stage $(n=825)$, although no significant differences were found among stages $\left(F_{2,275}=1.57, p=0.210\right)$. The flycatcher $T$. verticalis remained for the longest time in the trees of the early stage $(6.78 \pm 1.30 \mathrm{~min})$, T. vociferans in 
322 the intermediate stage $(6.33 \pm 1.13 \mathrm{~min})$ and E. canicularis in the mature stage $(8.00 \pm 4.00 \mathrm{~min}$;

323 Table 1).

324

\section{Seed germination}

The shortest average seed retention time from fruit intake until evacuation was recorded

for Myiarchus nuttingi and the highest for M. tyrannulus (Table 2). The latter had the widest

range in seed evacuation time (minimum $=10 \mathrm{~min}$ and $\operatorname{maximum}=230 \mathrm{~min})$. The shortest average timeframe corresponded to Myiodynastes luteiventris (minimum $=12 \mathrm{~min}$ and maximum $=155 \mathrm{~min}$; Table 2$)$, although differences in retention time were not significant $\left(F_{4,122}=0.98, p\right.$ $=0.420)$. Body size of the frugivorous birds was positively correlated with time of passage of $B$. longipes seeds $\left(R^{2}=0.79, F=11.68, p=0.04\right)$. without pseudoaril (control group 2) had a germination rate of $10 \%$. The seeds that passed through the gut of Myiarchus cinerascens had the highest germination percentage $(27 \%, n=33)$, followed by Myiarchus tyrannulus $(26 \%, n=27)$, Melanerpes chrysogenys $(24 \%, n=29)$, Myiarchus nuttingi $(15 \%, n=67)$ and Myiodynates luteiventris $(12 \%, n=58)$ (Fig. 2). pairwise t-test comparisons indicated that the three bird species associated with the highest percentage of germination (M. cinerascens, M. tyrannulus and M. chrysogenys) significantly differed in comparison to seeds without pseudoaril (control group 2, $p<0.01$ ) (Fig. 3). However, significant differences were not found in germination between seeds without pseudoaril (control group 2) and seeds eaten by $M$. nuttingi and $M$. luteiventris. The passage time of seeds through 
344 the gut and the germination percentage were marginally significant $\left(R^{2}=0.71, F=7.69, p=\right.$

345 0.06). Body size was not significantly correlated with germination percentage $(p>0.05)$.

\section{Potential suitable sites for recruitment}

After consuming fruits, birds perched in three categories of plants (Fig. 4). The

preference was for Fabaceae species at all three stages $\left(X^{2}=22.98, d f=12, p<0.05 ; X^{2}=55.33\right.$,

$d f=20, p<0.05 ; X^{2}=54.98, d f=20, p<0.05$, for the early, intermediate and mature stages,

351

respectively) (Fig. 4a-c). At the intermediate and mature stages, flycatchers $M$. nuttingi and $M$. tuberculifer remained for the longest period of time in Acacia and Mimosa plants following feeding episodes, while Tyrannus verticalis and Vireo gilvus spent more time in the same trees where they feeded on fruits. Thus, flycatchers of the Myiarchus genus were the most likely species to deposit B. longipes seeds beneath Mimosa and Acacia trees and shrubs across the three successional stages (Table 4).

\section{Contribution of birds to sites of seedling establishment}

The lowest density of $B$. longipes seedlings and non-reproductive individuals was found at the early stage $(0.002$ ind $/ \mathrm{m} 2)$. The average height of plants was $54.07 \pm 7.90 \mathrm{~cm}$. At the intermediate and mature stages, densities of seedlings and non-reproductive individuals were $0.007 \mathrm{ind} / \mathrm{m} 2$ and 0.008 ind $/ \mathrm{m} 2$, with an average height of $50.93 \pm 3.90 \mathrm{~cm}$ and $53.19 \pm 3.80$ $\mathrm{cm}$, respectively, and did not differ significantly in density $\left(F_{2,5}=0.89, p=0.50\right)$ or in average height $\left(F_{2,104}=0.12, p=0.89\right)$.

At the early stage, the number of seedlings and young $B$. longipes individuals was significantly higher under Tecoma stans, Plocosperma buxifolium and Mimosa polyantha plants 
367 (Table 3). At the intermediate stage, the largest number of seedlings was found under Mimosa 368 polyantha and Calliandra eryophylla, and at the mature stage, under Eysenhardtia polystachya,

369 Senna wislizeni, Sebastiana pavoniana and Acacia cochliacantha (Table 3). Acacia subangulata

370 was the only legume that presented a lower number of observed seedlings than expected by

371 chance (Table 3$)$.

372 The largest contribution to the establishment of $B$. longipes seedlings, calculated based on 373 the number of flights to nurse plants with the largest number of observed seedlings with respect

374 what would be expected by chance, was attributed to $M$. cinerascens at the early stage and to $M$.

375 nuttingi at the intermediate and mature stages (Table 4).

376

\section{Seed dispersal effectiveness}

The effectiveness of seed dispersal was estimated for five bird species whose number of visits allowed for a reliable estimation, which varied depending on the stage (Table 4). For other species, dispersion was not determined due to lack of defecated seeds or other subcomponents that would allow for this assessment.

At all stages the best dispersers belonged to the genus Myiarchus. At the early stage, only M. cinerascens contributed to seed dispersion (Table 4). At the intermediate stage, $M$. nuttingi was the largest contributor to seed dispersion. In the mature stage, five species participated in seed dispersion, and $M$. cinerascens had the highest effectiveness (Table 4).

\section{Discussion}

Bursera longipes fruits were consumed by birds in all successional stages, although bird species participating in seed dispersal, their importance and plants used for perching after feeding varied among stages. Both the number of fruit-eating species and the frequency of bird 
391 visits were lower in the early successional stage. This result concurs with the reports of Cordeiro

392 \& Howe (2003) and Figueroa-Esquivel et al. (2009), whom also note that at disturbed sites, the

393 number frugivorous bird species and their frequency tends to decrease due to a lower supply of

394 resources. Since lower number of frugivores are found in early-successional stages, there is less

395 redundancy in their dispersal community. Also, bird assemblages between seral stages may be

396 complementary because there are differences in functional diversity, which is mainly driven by

397 their differences in movement, foraging behavior, as well as body size (Calviño-Cancela \&

398 Martin-Herrero, 2009; Escribano-Avila et al., 2014).

399

Although several bird species removed many fruits and consistently visited B. longipes

400

trees at all three stages, not all birds contributed to the effective dispersal of its seeds. For

401

example, Spinus psaltria and Eupsittula canicularis had the highest rate of fruit removal at all

402

three stages. S. psaltria chews the seeds' pseudoaril and later discards seeds under the parent

403

plant, which reduces chances of germination and establishment due to competition with other

404

conspecifics (Jordano \& Schupp, 2000; Bas, Pons \& Gómez, 2005). In fact, we did not observe

405

juvenile plants of B. longipes growing in association with parent plants. E. canicularis destroyed

406 or damaged seeds upon handling them, and thus their contribution to dispersion was negative.

407 These results are consistent with those observed in other Neotropical plants, where the rate of

408 seed mortality increases due to predation by Psittacidae species (Francisco et al., 2008).

409

Previously, it was suggested that species of the Tyrannidae family, particularly from the

410

Myiarchus genus, could be the main legitimate dispersers of Bursera fruits, despite being largely

411

insectivorous (Ramos-Ordonez \& Arizmendi, 2011). In our study, ca. 70\% of the seeds at the

412 three stages were removed by Tyrannidae. Myiarchus spp. individuals, whose behavior is less

413 gregarious compared with other birds that also consume B. longipes fruits (e.g., genera Tyrannus, 
414 Eupsittula, Spinus) and who removed about 30\% of fruits at all stages. Two of these species are

415 latitudinal migrants (M. cinerascens and $M$. nuttingi), and other two have local altitudinal

416 migrations (M. tuberculifer and M. tyrannulus).

417 In the case of the M. cinerascens and M. nuttingi, the ripening time of B. longipes fruits

418 coincides with the winter presence of these birds. In winter, energy demands increase due to the

419 long distance movements of these species (Telleria, Ramírez \& Pérez-Tris, 2005), and the fruits

420 of Bursera spp. represent a source of lipids, which are present in the pseudoaril overlaying the

421 seeds (Ramos-Ordoñez, Arizmendi \& Márquez-Guzmán, 2012).

422

The distribution pattern of M. tuberculifer and M. tyrannulus apparently is determined by

423

424

425

426

427

428

429

430

431

432

433

434

435

436

supply of Bursera fruits (Almazán-Núñez et al., 2015), as the two bird species were only present at study sites during the fruiting season. These flycatchers were also observed during fruiting of B. morelensis in the Tehuacan Valley in Puebla (Arizmendi \& Ramos-Ordoñez, 2011). This is similar to the white-eyed vireo (Vireo griseus), whose presence and abundance was previously correlated with number of $B$. simaruba fruits in secondary growth forests in the Yucatan Peninsula (Greenberg, Foster \& Márquez-Valdelamar, 1995).

The distribution of Bursera spp. and particularly B. longipes seemingly coincides with that of the Myiarchus genus throughout the Neotropics, and in this study, these flycatchers have proven to be its most effective seed dispersers (sensu Schupp, 1995). The distribution of both groups is characteristic of semi-arid environments in the Neotropics, and these birds and the plant genera diversified during the Miocene (Ohlson, Fjeldsa \& Ericson, 2008; De-Nova et al., 2012). Both groups also generally adapt to anthropogenic disturbances throughout their range (Howell \& Webb, 1995; Rzedowski, Medina \& Calderón de Rzedowski, 2005), and this may also be a determinant factor of their recent success throughout Mesoamerican tropical forests. 
440 relatively far away from the mother plant, such as under nurse plants (Schupp, 1995; Godínez-

441 Alvarez \& Valiente-Banuet, 1998; Padilla \& Pugnaire, 2006).

Moreover, the germination rate of seeds that passed through the gut of $M$. cinerascens, $M$. tyrannulus and M. chrysogenys was significantly higher than seeds without pseudoaril (control group 2), although not in the case of $M$. nuttingi and M. luteiventris. While Bursera seeds responded to similar physiological treatments during endozoochory (Stevenson et al., 2002), germination differences between species can potentially be explained by time spent in the digestive system (Dominguez-Dominguez, Morales-Mávil \& Alba-Landa, 2006). M. nuttingi and M. luteiventris had a lower retention time; although these differences were not significant, there was a marginally positive significant relationship between gut passage time and germination, as found in other studies (Traveset, 1998). It is necessary to clarify that these results should be taken with caution because retention times represent an approximation. On the other hand, the size of the birds does not explain the percentage of germination. It is therefore possible that certain aspects of the digestive physiology of each bird species are more important than bird size in the subsequent germination of seeds. For example, some passerine birds retain the seeds in the gut for much longer than other birds (M. cinerascens, mean 129 min, versus M. chrysogenys, mean $80 \mathrm{~min}$ ), as also found by Jordano (1992). These bird species consume insects throughout 457 much of the year, but since their intestines are usually small, additional enzymatic attack is 458 required; in contrast to strict frugivores whose digestive system is usually longer (Jordano, 459 1986). 

soften the endocarp. As none of the seeds with intact pseudoaril germinated, the importance of

462 frugivorous birds in removing this tissue may be highlighted (Robertson et al., 2006), as these

463 tissues may contain substances that inhibit seed germination, similar to B. fagaroides (Ortiz

464 Pulido \& Rico-Gray, 2006). In this sense, Robertson et al. (2006) also indicated that the 465 deinhibition process may be more important than scarification of seeds. However, both phases 466 (deinhibition and scarification) are generally important for B. longipes seeds, and in general for 467 Bursera species, as shown in other studies (Ortiz Pulido \& Rico-Gray, 2006; Ramos-Ordoñez \& 468 Arizmendi, 2011).

The probability that $B$. longipes seeds are deposited by flycatchers of the genus

470 Myiarchus in suitable sites for germination, as well as the subsequent development of seedlings, confirms that these flycatchers are the most efficient seed dispersers across different successional

472 stages of dry forest. These dispersers often select perches belonging to species of Fabaceae, 473 which have been previously identified as nurse plants throughout several arid environments of 474 Mexico (Valiente-Banuet et al., 1991; Godínez-Alvarez \& Valiente-Banuet, 1998; Castillo \& 475 Valiente-Banuet, 2010). After eating fruits of B. longipes, Myiarchus species remain in the tree 476 for a brief duration of time and then generally move short distances to potential Fabaceae nurse 477 plants near Bursera trees. This behavior has been observed in other frugivorous birds (Wescott \& 478 Graham, 2000). In fact, in this study several species of Fabaceae (Senna wislizeni, Eysenhardtia 479 polystachya, Acacia cochliacantha, Calliandra eryophylla and Mimosa polyantha) were 480 important for the recruitment of $B$. longipes seedlings. This demonstrates the importance of 481 legumes in aiding seedling establishment, as they foster necessary conditions due to their 482 recycling of nutrients, accumulation of organic matter and shadow effect, which leads to more 
483 favorable temperatures for native plant development (Franco \& Nobel, 1989; Bonanomi et al., 484 2007). In addition, the spines of many of these species help to dispel potential predators of 485 seedlings (Khurana \& Singh, 2001).

486 On the other hand, only $M$. polyantha had more $B$. longipes seedlings in its vicinity than 487 expected by chance across the three successional stages, which suggests that in addition to 488 presence of nurse plants, other factors (e.g., soil water content, bulk density of soil, and $\mathrm{pH}$ ) 489 could be limiting the recruitment of B. longipes along the successional gradient (Buzzard et al., 490 2015). Therefore, the quality of microhabitats depends not only on presence of Fabaceae species 491 but also on biotic and abiotic factors that can limit seedling recruitment (Castillo \& Valiente492 Banuet, 2010).

493 Other members of the Tyrannidae family, such as T. verticalis and T. vociferans, have 494 been also considered to be dispersers, since they remove fruits in large quantities and swallow 495 whole seeds (Almazán-Núñez et al., 2015). However, they typically perch on the top branches of 496 B. longipes trees for long periods of time, and therefore, the quality of dispersal by these species 497 is low, because B. longipes crown does not seem to be suitable for recruitment of conspecific 498 seeds.

The observed number of recruited seedlings was lower in the early successional stage in 500 comparison to intermediate and mature stages. Mimosa polyantha was one of the nurse species 501 preferred by dispersers for perching; resulting in a higher recruitment of seeds, and consequently, 502 the number of seedlings under this plant was higher than expected by chance at all successional 503 stages. Similar results have been obtained for other species of the same nurse plant genus 504 (Castillo \& Valiente-Banuet, 2010). 
At the mature and intermediate stages, density of recruited seedlings increased due to

506

507

508

509

510

511

512

513

514

515

516

517

518

519

520

521

522

523

524

525

526

seed rain from dispersers, as found in other Neotropical forests (Vasconcellos-Neto, Barbosa \&

Rodrigues, 2009). The seed bank of the soil is also a likely influence and may have a lower density in earlier successional stages, as found at other TDF sites (Uhl, 1987; Hammond, 1995).

The presence of a seed bank fosters a higher rate of germination at advanced successional stages, which in addition to a high number of disperser visits would improve the microenvironmental conditions favoring seedling establishment (Valiente-Banuet et al., 1991; Godínez- Alvarez \& Valiente-Banuet, 1998; Orozco-Almanza et al., 2003; Padilla \& Pugnaire, 2006).

Although the number of frugivorous birds was lower in earlier successional stages (Almazán-Núñez et al., 2015), the presence of migratory dispersers that can tolerate disturbed sites ultimately contributes to the regeneration of these forests (Griscom et al., 2007; Tellería et al., 2014). Despite lower densities, seedlings recruited under nurse plants in the early stage were larger in size than seedlings found at other stages. However, it is also likely that the process of germination and establishment at this stage is slower than at other successional stages, mainly due to the more inhospitable conditions faced by seeds once they are dispersed (Padilla \& Pugnaire, 2006; Obeso, Martínez \& García, 2011). In this scenario, greater presence of legumes at early successional stages, as well as the preference of various dispersers to perch on these plants and the adaptability of some zoochorous plants to these new conditions, leads to a greater chance of recovering these habitats. Regional or genetic studies are necessary in order to analyze the spatial variability of seed dispersal and to further understand both the preferences and movements of frugivorous birds (Carlo, Aukema \& Morales, 2007; González-Varo, Arroyo \& Jordano, 2014), as well as differences in these factors in distinct regional environments. 
$60 \%$ in the next 40 years, according to scenarios of climate change (Miles et al., 2006; Prieto-

529 Torres et al., 2015). As a consequence, changes may occur in the fruiting phenology of trees that

530 could uncouple interactions with dispersers. Furthermore, climate changes could modify the

531 movement patterns of migratory birds, which are efficient dispersers of $B$. longipes seeds and

532 other species (Santos \& Tellería, 1995; Tellería et al., 2014).

533

\section{Acknowledgements}

535 We thank Hector Godínez, Pedro Luis Valverde and Maria Ramos Ordoñez for the critical

536 review of this document, as well as two anonymous reviewers who improved this manuscript.

537 We also appreciate the valuable support during fieldwork by Roberto Bahena, Trinidad Cruz, 538 Noemí González, Jeraldín González, Brenda Pérez, Pablo Sierra and Jaili Sánchez.

References

541

542

543

544

545

546

547

548

Almazán-Núñez RC, Arizmendi MC, Eguiarte LE, Corcuera P. 2012. Changes in composition, diversity and structure of woody plants in successional stages of tropical dry forest in southwest Mexico. Revista Mexicana de Biodiversidad 83:1096-1109. DOI: 10.7550/rmb.30403.

Almazán-Núñez RC, Arizmendi MC, Eguiarte LE, Corcuera P. 2015. Distribution of the community of frugivorous birds along a successional gradient in dry tropical forest in southwestern Mexico. Journal of Tropical Ecology 31:57-68. DOI: $10.1017 / \mathrm{S} 0266467414000601$. 
549 Bas JM, Pons P, Gómez C. 2005. Exclusive frugivory and seed dispersal of Rhamus alaternus in 550 the bird breeding season. Plant Ecology 183:77-89. DOI: $10.1007 /$ s1 1258-005-9008-0.

551 Becerra JX. 2005. Timing the origin and expansion of the Mexican tropical dry forest.

$552 \quad$ Proceedings of the National Academy of Sciences USA 102:10919-10923. DOI:

$553 \quad 10.1073 /$ pnas.0409127102.

554 Becerra JX, Noge K, Olivier S, Venable DL. 2012. The monophyly of Bursera and its impact for 555 divergence times of Burseraceae. Taxon 61:333-343.

556 Bonanomi G, Antignani V, Pane C, Scala F. 2007. Suppression of soilborne fungal diseases with 557 organic amendments. Journal of Plant Pathology 89:311-340.

558 Calviño-Cancela M. 2002. Spatial patterns of seed dispersal and seedling recruitment in Corema 559 album (Empetraceae): the importance of unspecialized dispersers for regeneration. Journal 560 of Ecology 90:775-784. DOI: 10.1046/j.1365-2745.2002.00711.x.

561

562

563

564

565

566

567

568

569 dispersers of a fleshy-fruited plant. Ecology 90:3503-3515. DOI: 10.1890/08-1629.1.

Carlo TA, Aukema JE, Morales JM. 2007. Plant-frugivore interactions as spatially explicit networks: integrating frugivore foraging with fruiting plant spatial patterns. In Dennis AJ, Schupp EW, Green RJ, Wescott DA, eds. Seed dispersal: theory and its application in a changing world. UK: CABI, Oxon, 369-390.

Castillo JP, Valiente-Banuet A. 2010. Species-specificity of nurse plants for the establishment, survivorship, and growth of a columnar cactus. American Journal of Botany 97:1289-1295. DOI: $10.3732 /$ ajb.1000088. 
570 Cordeiro NJ, Howe HF. 2003. Forest fragmentation severs mutualism between seed dispersers $571 \quad$ and an endemic African tree. Proceedings of the National Academy of Sciences USA 100:14052-14056. DOI: 10.1073/pnas.2331023100.

573 Crawley MJ. 2012. The R book. Chichester: John Wiley \& Sons.

574 De-Nova JA, Medina R, Montero JC, Weeks A, Rosell JA, Olson ME, Eguiarte LE, Magallón S.

575 2012. Insights into the historical construction of species-rich Mesoamerican seasonally dry 576 tropical forest: the diversification of Bursera (Burseraceae, Sapindales). New Phytologist 193:276-287. DOI: $10.1111 / j .1469-8137.2011 .03909$.

578

579

580

581

582

583

584 585

586

587

588

589

590

591

Dick CW, Wright J. 2005. Tropial mountain cradles of dry forest diversity. Proceedings of the National Academy of Sciences USA 102:10757-10758. DOI: 10.1073/pnas.0505013102.

Dominguez-Dominguez LE, Morales-Mávil JE, Alba-Landa J. 2006. Germinación de semillas de Ficus insipida (Moraceae) defecadas por tucanes (Ramphastos sulfuratus) y monos arañas (Ateles geoffroyi). Revista de Biología Tropical 54:387-394. DOI: $10.15517 /$ rbt.v54i2.13880.

Escribano-Avila G, Calviño-Cancela M, Pías B, Virgós E, Valladares F, Escudero A. 2014. Diverse guilds provide complementary dispersal services in a woodland expansion process after land abandonment. Journal of Applied Ecology 51:1701-1711. DOI: 10.1111/13652664.12340.

Figueroa-Esquivel E, Puebla-Olivares F, Godínez-Álvarez H, Núñez-Farfán J. 2009. Seed dispersal effectiveness by understory birds on Dendropanax arboreus in a fragmented landscape. Biodiversity and Conservation 18:3357-3365. DOI: 10.1007/s10531-009-9645- 
592 Forget PM, Jordano P, Lambert JE, Böhning-Gaese K, Traveset A, Wright SJ. 2011. Frugivores

593 and seed dispersal (1985-2010); the "seeds" dispersed, established and matured. Acta

594 Oecologica 37:517-520. DOI: 10.1016/j.actao.2011.09.008.

595 Francisco MR, Lunardi VO, Guimaraes PR, Galetti M. 2008. Factors affecting seed predation of 596 Eriotheca gracilipes (Bombacaeae) by parakeets in a cerrado fragment. Acta Oecologica 33:240-245. DOI: 10.1016/j.actao.2007.11.002.

598

599

600

601

602

603

604

605

606

607

608

609

610

611

612

613

614

Franco AC, Nobel PS. 1989. Effect of nurse plants on the microhabitat and growth of cacti. Journal of Ecology 77:870-886. DOI: 10.2307/2260991.

Godínez-Álvarez HO, Valiente-Banuet A, Rojas-Martínez A. 2002. The role of seed dispersers in the population dynamics of the columnar cactus Neobuxbaumia tetetzo. Ecology 83:2617-2629. DOI: 10.1890/0012-9658(2002)083[2617:TROSDI]2.0.CO;2.

Godínez-Álvarez H, Valiente-Banuet A. 1998. Germination and early seedling growth of Tehuacan Valley cacti species: the role of soils and seed ingestion by dispersers on seedling growth. Journal of Arid Environments 39:21-31. DOI: 10.1006/jare.1998.0376.

González-Varo JP, Arroyo JM, Jordano P. 2014. Who dispersed the seeds? The use of DNA barcoding in frugivory and seed dispersal studies. Methods in Ecology and Evolution 5:806-814. DOI: 10.1111/2041-210X.12212.

Greenberg R., Foster MS, Márquez-Valdelamar L. 1995. The role of the white-eyed vireo in the dispersal of Bursera fruit on the Yucatan Peninsula. Journal of Tropical Ecology 11:619639. DOI: $10.1017 / \mathrm{S} 0266467400009184$.

Griscom HP, Kalko EKV, Ashton MS. 2007. Frugivory by small vertebrates within a deforested, dry tropical region of Central America. Biotropica 39:278-282. DOI: 10.1111/j.17447429.2006.00242.x. 
615 Guízar E, Sánchez A. 1991 Guía para el reconocimiento de los principales árboles del alto

616 Balsas. Chapingo, México: Universidad Autónoma Chapingo.

617 Hammond DS. 1995. Post-dispersal seed and seedling mortality of tropical dry forest trees after

618 shifting agriculture, Chiapas, Mexico. Journal of Tropical Ecology 13:51-58. DOI:

619 $10.1017 / \mathrm{S} 0266467400008762$.

620

Howell SNG, Webb S. 1995. A guide to the birds of Mexico and northern Central America. New 621 York: Oxford University Press.

622

623

624

625

626

627

628

629

630

631

632

633

634

635

636

637

Jordano P. 1986. Frugivory, external morphology and digestive system in Mediterranean sylviid warblers Sylvia spp. Ibis 129:175-189. 10.1111/j.1474-919X.1987.tb03199.x.

Jordano P. 1992. Fruits and frugivory. In Fenner M, ed. Seeds - The ecology of regeneration in plant communities. Wallingford, UK: CAB International, 105-156.

Jordano P, Schupp E. 2000. Seed disperser effectiveness: the quantity component and patterns of seed rain for Prunus mahaleb. Ecological Monographs 70:591-615. DOI: 10.1890/00129615(2000)070[0591:SDETQC]2.0.CO;2.

Jordano P, Forget PM, Lambert JE, Böhning-Gaese K, Traveset A, Wright SJ. 2010. Frugivores and seed dispersal: mechanisms and consequences for biodiversity of a key ecological interaction. Biology Letters 7:321-323. DOI: 10.1098/rsb1.2010.0986.

Khurana E, Singh JS. 2001. Ecology of seed and seedling growth for conservation and restoration of tropical dry forest: a review. Environmental Conservation 28:39-52. DOI:

10.1017/S0376892901000042.

Martins AM, Engel VL. 2007. Soil seed banks in tropical forest fragments with different disturbance histories in southeastern Brazil. Ecological Engineering 37:1499-1506. DOI: 10.1016/j.ecoleng.2011.05.004. 
638 Miles L, Newton AC, DeFries R, Ravilious C, May I, Blyth S, Kapos V, Gordon J. 2006. A 639 global overview of the conservation status of tropical dry forests. Journal of Biogeography

640 33:491-505. DOI: 10.1111/j.1365-2699.2005.01424.x.

641 Obeso JR, Martínez I, García D. 2011. Seed size is heterogeneously distributed among 642 destination habitats in animal dispersed plants. Basic and Applied Ecology 12:134-140. 643 DOI: 10.1016/j.baae.2011.01.003.

644 Ohlson J, Fjeldsa J, Ericson PG. 2008. Tyrant flycatcher coming out in the open: phylogeny and 645 ecological distribution radiation of Tyrannidae (Aves: Passeriformes). Zoologica Scripta $646 \quad 37: 315-335$. DOI: 10.1111/j.1463-6409.2008.00325.x.

647 Orozco-Almanza MS, de León-García LP, Grether R, García-Moya E. 2003. Germination of four 648 species of the genus Mimosa (Leguminosae) in a semid-arid zona of Central Mexico. Journal of Arid Environments 55:75-92. DOI: 10.1016/S0140-1963(02)00265-3.

650

651

652

653

654

655

656

657

658

Ortiz-Pulido R, Rico-Gray V. 2006. Seed dispersal of Bursera fagaroides (Burseraceae): the effect of linking environmental factors. Southwestern Naturalist 51:11-21. DOI: 10.1894/0038-4909(2006)51[11:SDOBFB]2.0.CO;2.

Padilla FM, Pugnaire FI. 2006. The role of nurse plants in the restoration of degraded environments. Frontiers in Ecology and the Environment 4:196-202. DOI: 10.1890/15409295(2006)004[0196:TRONPI]2.0.CO;2.

Peña-Claros M, De Boo H. 2002. The effect of forest successional stage on seed removal of tropical rain forest tree species. Journal of Tropical Ecology 18:264-274. DOI: $10.1017 / \mathrm{S} 0266467402002171$. 
659 Pérez-Villafaña MG, Valiente-Banuet A. 2009. Effectiveness of dispersal of an ornithocorous 660 cactus Myrtillocactus geometrizans (Cactaceae) in a patchy environment. Open Biology Journal 2:101-113. DOI: 10.2174/1874196700902010101.

662 Prieto-Torres D, Navarro-Sigüenza AG, Santiago-Alarcón D, Rojas-Soto O. 2015. Response of 663 the endangered tropical dry forests to climate change and the role of Mexican protected 664 areas for their conservation. Global Change Biology 22:364-379. DOI: 10.1111/gcb.13090.

665 Quesada M, Sánchez-Azofeita GA, Álvarez-Añorve M, Stoner KE, Avila-Cabadilla L, Calvo666 Alvarado J, Castillo A, Espírito-Santo MM, Fagundes M, Fernandes GW, Gamon J, Lopezaraiza-Mikel M, Lawrence B, Cerdeira BLP, Powers JS, Neves F, Rosas-Guerrero V, Sayago R, Sánchez-Montoya G. 2009. Succession and management of tropical dry forests in the Americas: review and new perspectives. Forest Ecology and Management 258:10141024. DOI: 10.1016/j.foreco.2009.06.023.

671

672

673

674

675

676

677

678

679

680

681

Ralph CJ, Geupel GR, Pyle P, Martin TE, De Sante DF, Mila B. 1996. Manual de métodos de campo para el monitoreo de aves terrestres. Albany, California: General Technical Report, PSW-GTR-159. Pacific Southwest Research Station, Forest Services, U.S. Department of Agriculture.

Ramos-Ordoñez MF, Arizmendi MC. 2011. Parthenocarpy, attractiveness and seed predation by birds in Bursera morelensis. Journal of Arid Environments 75:757-762. DOI: 10.1016/j.jaridenv.2011.04.013.

Ramos-Ordoñez MF, Arizmendi MC, Márquez-Guzmán J. 2012. The fruit of Bursera: structure, maturation and parthenocarpy. AoB PLANTS DOI: 10.1093/aobpla/pls027.

Robertson AW, Trass A, Ladley JJ, Kelly D. 2006. Assessing the benefits of frugivory for seed germination: the importance of the deinhibition effect. Functional Ecology 20:58-66. DOI: 
682 683 684 685 686 687 688 689 690 691 692 693 10.1111/j.1365-2435.2005.01057.x. Rzedowski J. 1978. Vegetación de México. México, DF: Limusa.

Rzedowski J, Medina R, Calderón de Rzedowski G. 2005. Inventario del conocimiento taxonómico, así como de la diversidad y del endemismo regionales de las especies mexicanas de Bursera (Burseraceae). Acta Botánica Mexicana 70:85-111.

Santos T, Tellería JL. 1995. Global environmental change to and the future of Mediterranean forest avifauna. In: Moreno JM, Oechel WC, eds. Global change and Mediterranean-type ecosystems. New York: Springer, 457-470.

Schupp EW. 1993. Quantity, quality and the effectiveness of seed dispersal by animals. Vegetatio 107/108:15-29. DOI: 10.1007/BF00052209.

Schupp EW. 1995. Seed-seedling conflicts, habitat choice, and patterns of plant recruitment. American Journal of Botany 82:399-409. DOI: DOI: 10.2307/2445586.

Schupp EW, Milleron T, Russo S. 2002. Dissemination limitation and the origin and maintenance of species-rich tropical forests. In Levey DJ, Silva W, Galetti M, eds. Seed dispersal and frugivory: ecology, evolution and conservation. UK: CAB International, Wallingford, 19-33.

Schupp EW., Jordano P, Gómez JM. 2010. Seed dispersal effectiveness revisited: a conceptual review. New Phytologist 188:333-353. DOI: 10.1111/j.1469-8137.2010.03402.x

Shiels AB, Walker LR. 2003. Bird perches increase forest seeds on Puerto Rico landslides. Restoration Ecology 11:457-465. DOI: 10.1046/j.1526-100X.2003.rec0269.x

Spiegel O, Nathan R. 2007. Incorporating dispersal distance into the disperser effectiveness framework: frugivorous birds provide complementary dispersal to plants in a patchy environment. Ecology Letters 10:718-728. DOI: 10.1111/j.1461-0248.2007.01062. 
705 706

707 708

709

710

711

712

713

714

715

716

717

718

719

720

721

722

723

724

725

726

SPSS. 2008. SPSS for Windows. Release 17.0. Chicago: Statistical Package for Social Sciences Inc.

Stevenson PR, Castellanos MC, Pizarro JC, Garavito M. 2002. Effects of seed dispersal by three Ateline Monkey species on seed germination at Tinigua National Park, Colombia. International Journal of Primatology 23:1187-1204.

Tellería JL, Ramírez A, Pérez-Tris J. 2005. Conservation of seed-dispersing migrant birds in Mediterranean habitats: shedding light on patterns to preserve processes. Biological Conservation 124:493-502. DOI: 10.1016/j.biocon.2005.02.011.

Tellería JL, Carrascal LM, Santos T. 2014. Species abundance and migratory status affects largescale fruit tracking in thrushes (Turdus spp.). Journal of Ornithology 155:157-164. DOI: 10.1007/s10336-013-0997-5.

Thompson JN. 2005. The geographic mosaic of coevolution. Chicago: The University of Chicago Press.

Thompson K, Grime JP, Mason G. 1997. Seed germination in response to diurnal fluctuations of temperature. Nature 267:147-149. DOI: 10.1038/267147a0.

Traveset A. 1998. Effect of seed passage through vertebrate frugivores' guts on germination: a review. Perspectives in Plant Ecology, Evolution and Systematics 1:151-190. DOI: $10.1078 / 1433-8319-00057$.

Uhl C. 1987. Factor controlling succession following slash-and-burn agriculture in Amazonia. Journal of Ecology 75:377-407. DOI: 10.2307/2260425.

Valiente-Banuet A, Briones O, Bolongaro-Crevenna A, Ezcurra E, Rosas M, Nlifiez H, Barnard G, Vizquez E. 1991. Spatial relationships between cacti and nurse shrubs in a semi-arid 
environment in central Mexico. Journal of Vegetation Science 2:15-20. DOI: $10.2307 / 3235893$.

729

730

731

732

733

734

735

736

737

738

739

740

741

742

743

744

745

746

747

748

749

\section{2}

Valiente-Banuet A, Molina-Freaner F, Torres A, Arizmendi MC, Casas A. 2004. Geographic differentiation in the pollination system of the columnar cactus Pachycereus pectenaboriginum. American Journal of Botany 91:850-855. DOI: 10.3732/ajb.91.6.850.

Vasconcellos-Neto J, Barbosa L, Rodrigues W. 2009. Acta Botanica Brasilica 23:1171-1179. DOI: $10.1590 / \mathrm{S} 0102-33062009000400027$.

Westcott DA, Graham DL. 2000. Patterns of movement and seed dispersal of a tropical frugivore. Oecologia 122:249-257. DOI: 10.1007/PL00008853.

Wright SJ. 2007. Seed dispersal in anthropogenic landscapes. In Dennis AJ, Schupp EW, Green RJ, Westcott DA, eds. Seed dispersal: theory ans its application in a changing world. UK: CABI, Oxon, 599-614.

(n)

1


750 Table 1. Frequency of visits (visits/hr-observation), fruits and time spent per visit of birds that

751 consumed $B$. longipes fruits in three successional stages of tropical dry forest in the Balsas basin

752 of Guerrero, Mexico. The values shown are as the mean \pm standard error.

753

754

755

756

757

758

759

760

761

762

763

764

765

766

767

768 
Table 1.

\begin{tabular}{|c|c|c|c|c|c|c|c|c|c|c|}
\hline \multirow[b]{2}{*}{ Family } & \multirow[b]{2}{*}{ Species } & \multicolumn{3}{|c|}{ Early succession } & \multicolumn{3}{|c|}{ Intermediate succession } & \multicolumn{3}{|c|}{ Mature succession } \\
\hline & & $\begin{array}{l}\text { Freq. } \\
\text { Visit }\end{array}$ & $\begin{array}{c}\text { Fruits/ } \\
\text { visit }\end{array}$ & $\begin{array}{c}\text { Time/ } \\
\text { visit }\end{array}$ & $\begin{array}{l}\text { Freq. } \\
\text { Visit }\end{array}$ & $\begin{array}{c}\text { Fruits/ } \\
\text { visit }\end{array}$ & $\begin{array}{c}\text { Time/ } \\
\text { visit }\end{array}$ & $\begin{array}{l}\text { Freq. } \\
\text { Visit }\end{array}$ & $\begin{array}{c}\text { Fruits/ } \\
\text { visit }\end{array}$ & $\begin{array}{c}\text { Time/ } \\
\text { visit }\end{array}$ \\
\hline Psittacidae & Eupsittula canicularis & - & - & - & - & - & - & 0.029 & $11.00 \pm 4.00$ & $8.00 \pm 4.00$ \\
\hline Picidae & Melanerpes chrysogenys & - & - & - & 0.057 & $2.25 \pm 0.25$ & $2.75 \pm 0.48$ & 0.071 & $2.66 \pm 0.56$ & $2.83 \pm 0.53$ \\
\hline \multirow[t]{8}{*}{ Tyrannidae } & Myiarchus tuberculifer & - & - & - & 0.043 & $2.00 \pm 0.58$ & $2.40 \pm 0.83$ & 0.086 & $1.83 \pm 0.31$ & $4.17 \pm 0.65$ \\
\hline & M. cinerascens & 0.086 & $2.50 \pm 0.43$ & $3.33 \pm 0.99$ & 0.257 & $2.11 \pm 0.42$ & $2.56 \pm 0.37$ & 0.243 & $2.52 \pm 0.37$ & $4.07 \pm 0.34$ \\
\hline & M. nuttingi & - & - & - & 0.143 & $2.20 \pm 0.53$ & $4.00 \pm 0.68$ & 0.1 & $2.77 \pm 0.62$ & $4.17 \pm 0.76$ \\
\hline & M. tyrannulus & 0.129 & $3.77 \pm 0.52$ & $5.00 \pm 0.76$ & 0.143 & $2.40 \pm 0.37$ & $4.90 \pm 1.22$ & 0.114 & $1.75 \pm 0.49$ & $2.00 \pm 0.46$ \\
\hline & Myiodynastes luteiventris & 0.029 & $3.50 \pm 1.50$ & $2.75 \pm 0.25$ & - & - & - & 0.071 & $4.33 \pm 0.56$ & $5.50 \pm 0.99$ \\
\hline & Tyrannus melancholicus & - & - & - & 0.014 & 5 & 10 & - & - & - \\
\hline & T. vociferans & - & $1.50 \pm 0.50$ & $1.75 \pm 0.25$ & 0.3 & $3.00 \pm 0.43$ & $6.33 \pm 1.13$ & 0.214 & $2.56 \pm 0.52$ & $4.41 \pm 0.60$ \\
\hline & T. verticalis & 0.129 & $4.11 \pm 0.98$ & $6.78 \pm 1.30$ & 0.3 & $3.52 \pm 0.59$ & $5.76 \pm 1.02$ & 0.129 & $5.45 \pm 0.76$ & $6.31 \pm 1.13$ \\
\hline Corvidae & Calocitta formosa & - & - & - & 0.029 & $3.00 \pm 1.00$ & $2.50 \pm 0.50$ & - & - & - \\
\hline Vireonidae & Vireo gilvus & - & - & - & - & - & - & 0.029 & $1.00 \pm 0.00$ & $1.50 \pm 0.50$ \\
\hline \multirow[t]{4}{*}{ Cardinalidae } & Passerina caerulea & 0.043 & $1.00 \pm 0.00$ & $1.83 \pm 1.09$ & 0.029 & $1.50 \pm 0.50$ & $5.00 \pm 2.00$ & - & - & - \\
\hline & P. versicolor & 0.029 & $1.00 \pm 0.00$ & $3.00 \pm 2.00$ & 0.114 & $2.38 \pm 0.46$ & $4.31 \pm 1.02$ & - & - & - \\
\hline & P. leclancherii & - & - & - & 0.029 & $2.00 \pm 0.00$ & $3.50 \pm 0.50$ & 0.029 & $1.50 \pm 0.50$ & $5.00 \pm 1.00$ \\
\hline & Pheucticus melanocephalus & - & - & - & - & - & - & 0.043 & $3.33 \pm 1.86$ & $6.83 \pm 4.28$ \\
\hline Emberizidae & Haemorhous mexicanus & - & - & - & 0.043 & $3.00 \pm 0.00$ & $3.67 \pm 0.88$ & - & - & - \\
\hline \multirow[t]{2}{*}{ Icteridae } & Icterus wagleri & 0.029 & $2.00 \pm 0.00$ & $2.00 \pm 0.00$ & 0.029 & $2.50 \pm 1.50$ & $5.00 \pm 2.00$ & 0.029 & $5.00 \pm 1.00$ & $3.25 \pm 1.75$ \\
\hline & I. pustulatus & 0.086 & $3.83 \pm 0.87$ & $3.33 \pm 0.80$ & 0.257 & $2.17 \pm 0.26$ & $3.27 \pm 0.49$ & 0.086 & $4.83 \pm 1.33$ & $8.50 \pm 1.72$ \\
\hline Fringillidae & Spinus psaltria & 0.057 & $5.00 \pm 1.58$ & $4.25 \pm 1.16$ & 0.071 & $4.40 \pm 0.51$ & $5.00 \pm 0.89$ & 0.029 & $2.00 \pm 0.58$ & $2.83 \pm 0.17$ \\
\hline
\end{tabular}


772

773 Table 2. Average seed retention time from point of seed consumption to defecation by captured

774 birds. S.E. = Standard Error.

775

\begin{tabular}{llllll}
\hline Statistics & Myicin & Myinut & Myityr & Myilut & Melchr \\
\hline Average time (min) & 104 & 60 & 129 & 69 & 80 \\
Standar Error & 11.3 & 5.8 & 23.0 & 8.2 & 11.0 \\
Minimum & 22 & 18 & 10 & 12 & 7 \\
Maximum & 225 & 179 & 230 & 155 & 155
\end{tabular}

776 Myicin (Myiarchus cinerascens), Myinut (Myiarchus nuttingi), Myityr (Myiarchus tyrannulus), Myilut

777 (Myiodynastes luteiventris), Melchr (Melanerpes chrysogenys).

778

779

780

781

782

783

784

785

786

787

788

789

790

791

792

793 
794 Table 3. Standardized Residuals (StaRes) for the number of B. longipes seedlings $(<50 \mathrm{~cm})$

795 according to observed (Obs) and expected (Exp) coverage under nurse plants including two

796 categories: other tree and shrub species and Fabaceae species. Residual values $>2$ are significant

797 at a 95\% confidence level for a normal distribution.

\begin{tabular}{|c|c|c|c|c|c|c|c|c|c|c|}
\hline \multirow[b]{2}{*}{ Plant species } & \multirow[b]{2}{*}{ Family } & \multicolumn{3}{|c|}{$\begin{array}{l}\text { Early } \\
\text { Stage }\end{array}$} & \multicolumn{3}{|c|}{$\begin{array}{c}\text { Intermediate } \\
\text { Stage }\end{array}$} & \multicolumn{3}{|c|}{$\begin{array}{l}\text { Mature } \\
\text { Stage }\end{array}$} \\
\hline & & Obs & Exp & StaRes & Obs & Exp & StaRes & Obs & Exp & StaRes \\
\hline \multicolumn{11}{|c|}{ Other tree and shrub species } \\
\hline Tecoma stans & Bignoniaceae & 1 & 0.1 & 3 & 1 & 0.3 & 1.3 & 0 & 0 & -0.2 \\
\hline Cordia sp & Boraginaceae & 1 & 1.9 & -0.7 & 0 & 1.2 & -1.1 & 1 & 0.8 & 0.3 \\
\hline Opuntia sp & Cactaceae & 0 & 0.2 & -0.4 & 1 & 0.2 & 1.6 & 0 & 0 & 0 \\
\hline Ipomoea pauciflora & Convolvulaceae & 0 & 0.5 & -0.7 & 0 & 2.7 & -1.6 & 1 & 1.2 & -0.1 \\
\hline Euphorbia schlechtendalii & Euphorbiaceae & 0 & 0.1 & -0.3 & 0 & 2.4 & -1.6 & 1 & 0.7 & 0.4 \\
\hline Sebastiana pavoniana & Euphorbiaceae & 0 & 0 & 0 & 0 & 0 & 0 & 1 & 0.2 & 2.2 \\
\hline Plocosperma buxifolium & Loganiaceae & 1 & 0.1 & 3.1 & 0 & 2.7 & -1.6 & 1 & 0.6 & 0.5 \\
\hline Ziziphus amole & Rhamnaceae & 0 & 0 & 0 & 0 & 0 & 0 & 1 & 0.8 & 0.2 \\
\hline Randia sp & Rubiaceae & 0 & 0 & 0 & 1 & 0.3 & 1.2 & 0 & 0 & 0 \\
\hline Cissus sp. & Vitaceae & 1 & 1.3 & -0.2 & 6 & 3 & 1.8 & 0 & 0.5 & -0.7 \\
\hline \multicolumn{11}{|l|}{ Fabaceae species } \\
\hline Senna wislizeni & Fabaceae & 2 & 0.7 & 1.5 & 3 & 1.1 & 1.8 & 8 & 2.9 & 3 \\
\hline Senna skinneri & Fabaceae & 0 & 0 & 0 & 2 & 1.2 & 0.8 & 0 & 0.3 & -0.5 \\
\hline Eysenhardtia polystachya & Fabaceae & 0 & 0.5 & -0.7 & 0 & 3.5 & -1.9 & 2 & 0.2 & 4.4 \\
\hline Gliricidia sepium & Fabaceae & 3 & 3.5 & -0.3 & 0 & 3.3 & -1.8 & 0 & 0.8 & -0.9 \\
\hline Havardia acatlensis & Fabaceae & 2 & 1.5 & 0.4 & 3 & 4.3 & -0.6 & 1 & 2.7 & -1 \\
\hline Pterocarpus acapulcensis & Fabaceae & 0 & 0.3 & -0.6 & 2 & 4.1 & -1 & 3 & 8.5 & -1.9 \\
\hline Acacia cochliacantha & Fabaceae & 1 & 1.4 & -0.3 & 2 & 0.7 & 1.5 & 9 & 3.1 & 3.3 \\
\hline Acacia subangulata & Fabaceae & 0 & 0.9 & -1 & 3 & 6.1 & -1.3 & 5 & 13.6 & -2.3 \\
\hline Calliandra eryophylla & Fabaceae & 0 & 0 & 0 & 4 & 0.7 & 4 & 0 & 0 & 0 \\
\hline Desmanthus balsensis & Fabaceae & 0 & 0 & 0 & 0 & 0.7 & -0.9 & 3 & 3.5 & -0.2 \\
\hline Lysiloma tergemina & Fabaceae & 0 & 0.5 & -0.7 & 5 & 2.5 & 1.5 & 2 & 2.2 & -0.2 \\
\hline Mimosa polyantha & Fabaceae & 2 & 0.4 & 2.3 & 10 & 1.9 & 5.9 & 9 & 4.6 & 2.1 \\
\hline
\end{tabular}

798 Significant values of standardized residuals (StaRes) for each successional stage are highlighted in bold.

799

800

801

802 
803 Table 4. Probability of seed deposition, contribution to the establishment of seedlings and

804 effectiveness of $B$. longipes seed dispersal by frugivorous birds in a successional gradient of

805 tropical dry forest in the Balsas basin of Guerrero, Mexico.

806

\begin{tabular}{|c|c|c|c|c|c|c|c|c|c|}
\hline \multirow[t]{2}{*}{ Species } & \multicolumn{3}{|c|}{$\begin{array}{l}\text { Probability of } B \text {. longipes seed } \\
\text { deposition in secure sites }\end{array}$} & \multicolumn{3}{|c|}{$\begin{array}{l}\text { Value of contribution to the } \\
\text { establishment of } B \text {. longipes } \\
\text { seedlings in secure sites }\end{array}$} & \multicolumn{3}{|c|}{ Seed dispersal effectiveness } \\
\hline & Early & Intermediate & Mature & Early & Intermediate & Mature & Early & Intermediate & Mature \\
\hline C. formosa & - & 0.02 & - & - & - & - & - & - & - \\
\hline I. pustulatus & 0.15 & 0.07 & 0.05 & 0.16 & 0.6 & - & - & - & - \\
\hline I. wagleri & 0.05 & 0.01 & 0.02 & - & 0.2 & - & - & - & - \\
\hline M. chrysogenys & - & 0.02 & 0.06 & - & 0.2 & 0.25 & 0 & 0.015 & 0.08 \\
\hline M. cinerascens & 0.29 & 0.18 & 0.17 & 1 & 0.2 & 0.5 & 1.69 & 0.52 & 1.72 \\
\hline M. luteiventris & 0.05 & - & 0.09 & - & - & 0.25 & 0 & 0 & 0.10 \\
\hline M. nuttingi & - & 0.18 & 0.09 & - & 1 & 1 & 0 & 0.84 & 0.48 \\
\hline M. tuberculifer & - & 0.12 & 0.08 & - & - & 0.25 & - & - & - \\
\hline M. tyrannulus & 0.20 & 0.14 & 0.08 & - & 0.4 & 0.25 & 0 & 0.51 & 0.10 \\
\hline T. melancholicus & - & 0.02 & - & - & - & - & - & - & - \\
\hline T. verticalis & 0.17 & 0.14 & 0.11 & - & 0.4 & 0.25 & - & - & - \\
\hline T. vociferans & 0.10 & 0.08 & 0.25 & - & - & 0.50 & - & - & - \\
\hline V. gilvus & - & - & 0.01 & - & - & - & - & - & - \\
\hline
\end{tabular}

808

809

810

811

812

813

814 
815 Figure 1. Projection of the (a) Balsas basin, (b) distribution of Bursera longipes in the biotic

816 province of the Balsas basin (c) and study area. Photograph of B. longipes in the (a) rainy season

817 with presence of foliage, (b) in the dry season with the presence of ripe fruit and (c) pseudoaril

818 overlaying the seeds.

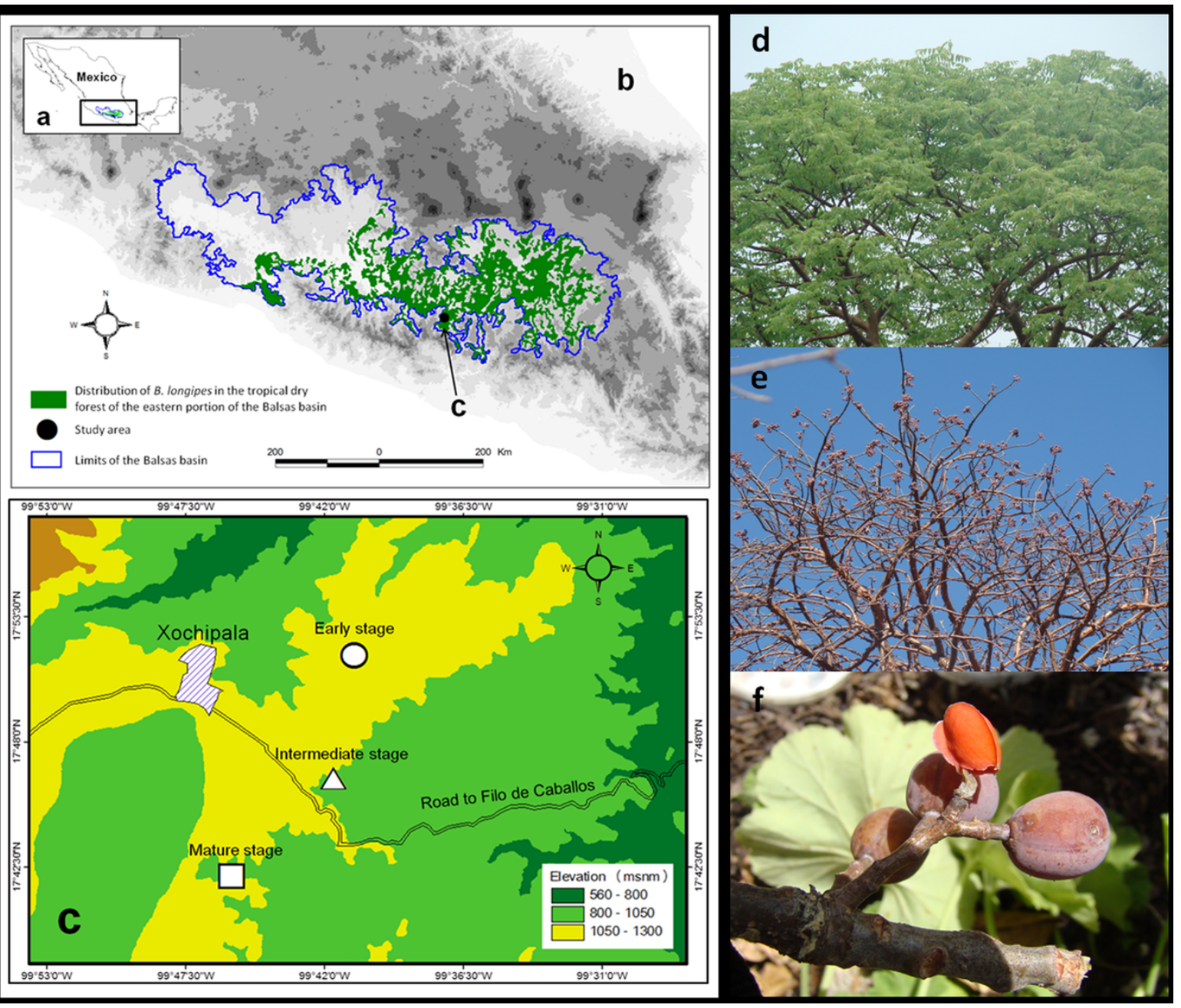


825 Figure 2. Seed germination of B. longipes after passing through the digestive system of birds in

826 comparison to control group 1 (seed with pseudoaril) and control group 2 (seeds without

827 pseudoaril).

828

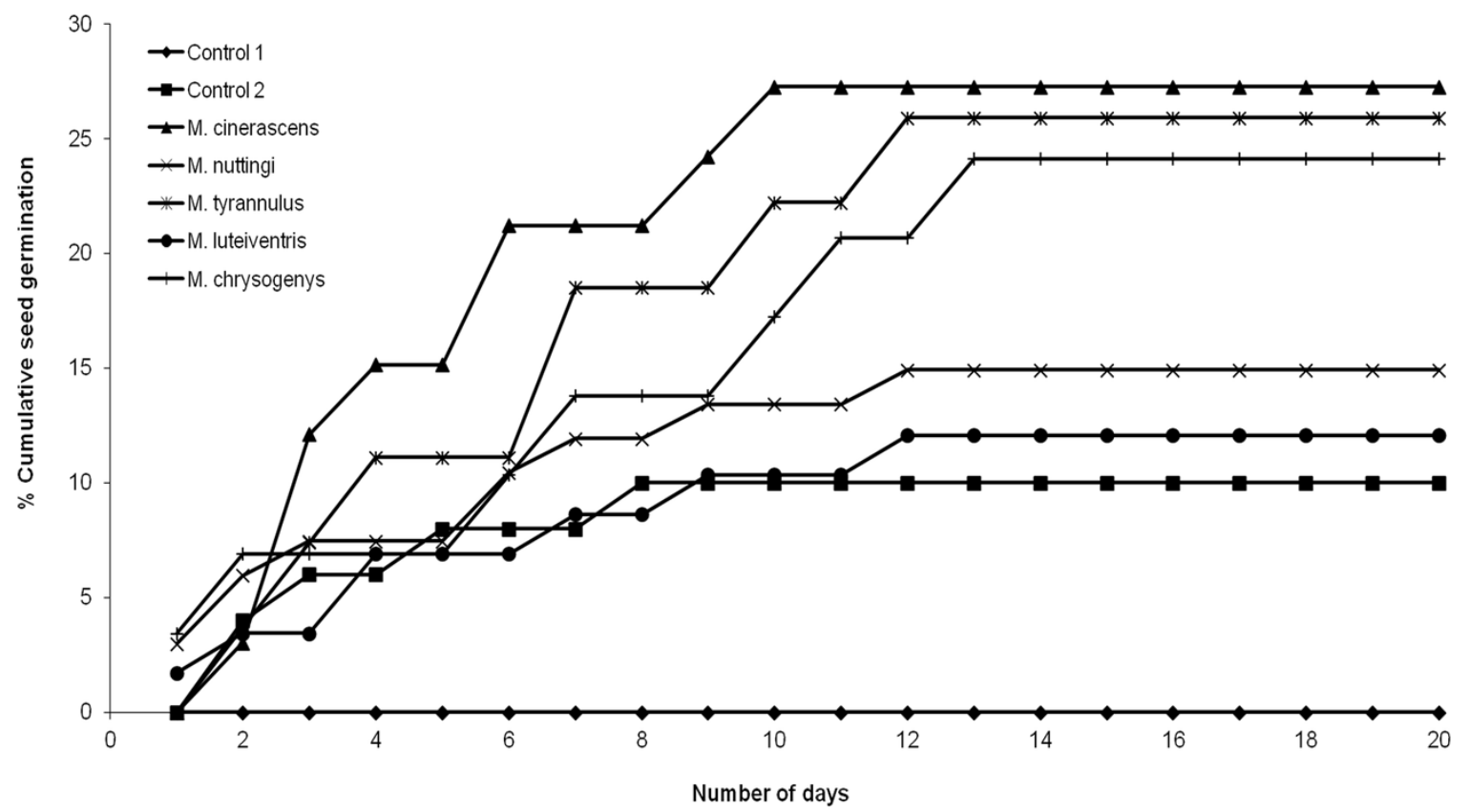

829

830

831

832

833

834

835

836

837

838

839 
840 Figure 3. Proportion of seeds germinated after passing through the digestive system of birds.

841 Different letters among treatments indicate significant differences (T-test comparisions, $p<$ $8420.05)$.

843

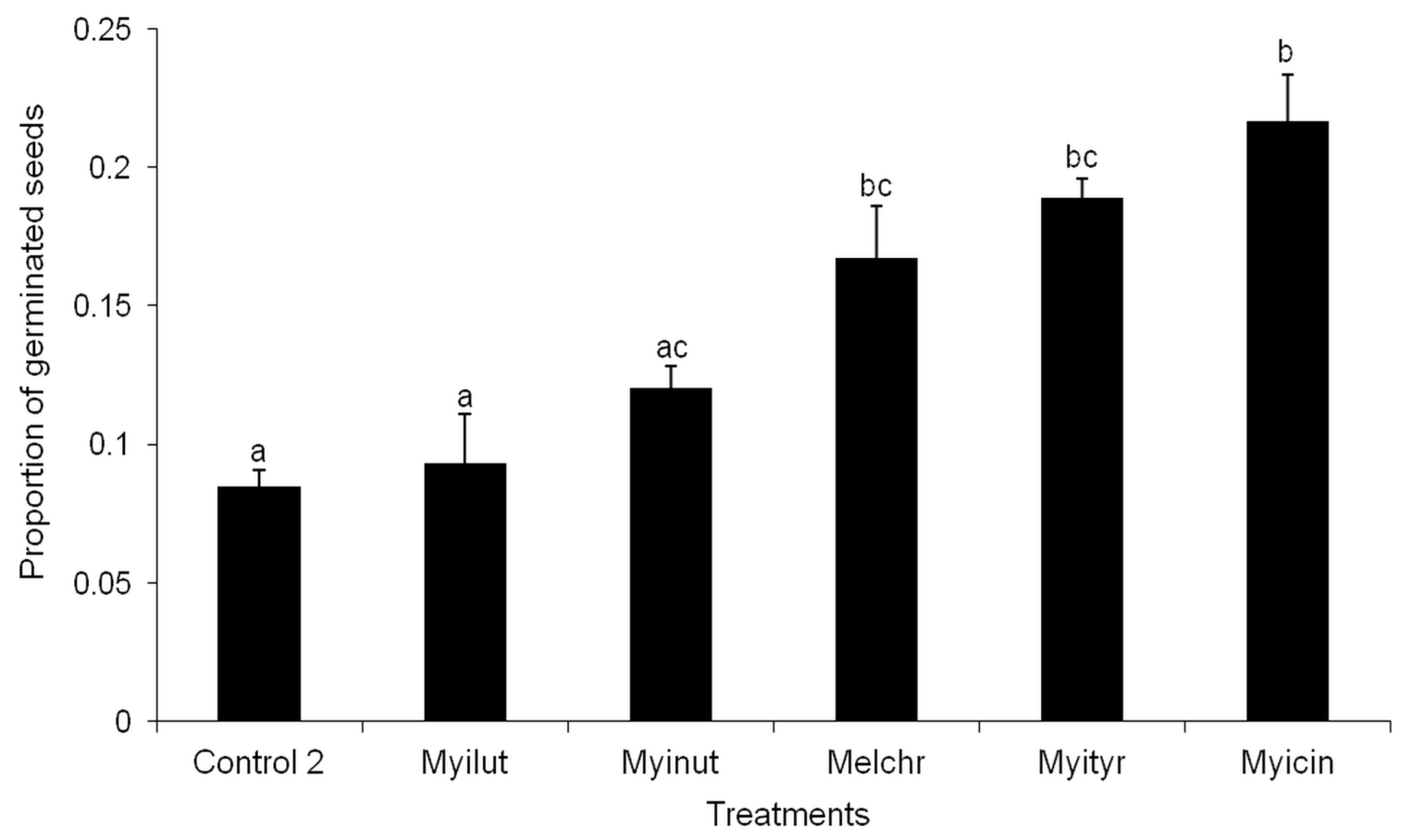


856 Figure 4. Residuals of a contingency table comparing perching sites for birds after consumption

857 of B. longipes fruit in three stages of succession: (a) early, (b) intermediate (c) mature. Bars

858 represent frequencies, and significant residuals indicate preference (positive residual) or

859 avoidance (negative residual) by each bird species. $* p<0.05, * * p<0.01$.

860

861

862

863

864

865

866

867

868

869

870

871

872

873

874

875

876

877

878

879 
Figure 4.
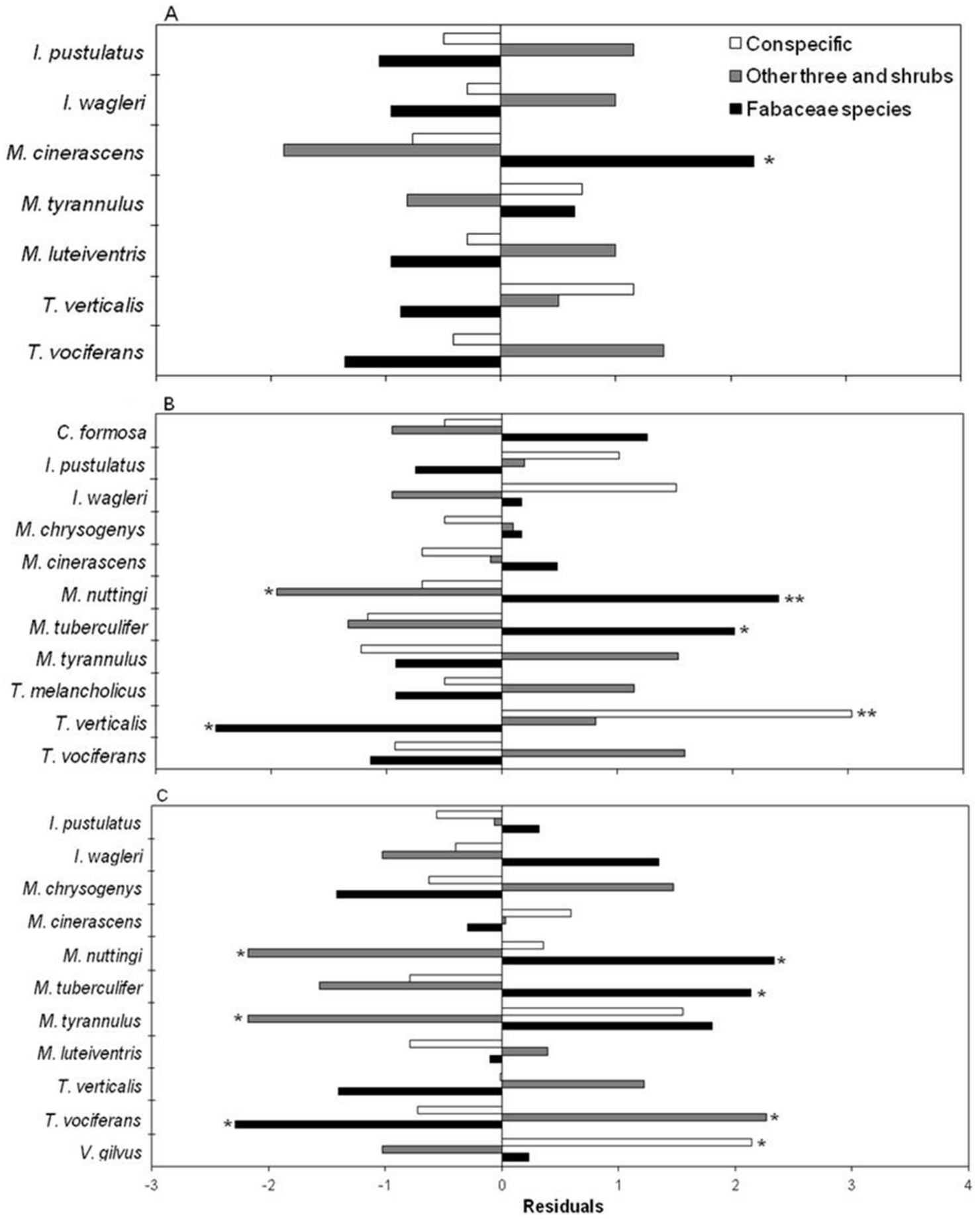